\title{
Measurement of circulating salmon IGF binding protein-1: assay development, response to feeding ration and temperature, and relation to growth parameters
}

\author{
Munetaka Shimizu ${ }^{1,2}$, Brian R Beckman ${ }^{1}$, Akihiko Hara ${ }^{3}$ and \\ Walton W Dickhoff ${ }^{1,2}$ \\ ${ }^{1}$ Northwest Fisheries Science Center, NOAA Fisheries, 2725 Montlake Boulevard East, Seattle, Washington 98112, USA \\ ${ }^{2}$ School of Aquatic and Fishery Sciences, University of Washington, Seattle, Washington 98195, USA \\ ${ }^{3}$ Graduate School of Fisheries Sciences, Hokkaido University, 3-1-1 Minato, Hakodate, Hokkaido 041-8611, Japan \\ (Requests for offprints should be addressed to M Shimizu; Email: munetaka.shimizu@noaa.gov)
}

\begin{abstract}
Fish plasma/serum contains multiple IGF binding proteins (IGFBPs), although their identity and physiological regulation are poorly understood. In salmon plasma, at least three IGFBPs with molecular masses of 22, 28 and $41 \mathrm{kDa}$ are detected by Western ligand blotting. The $22 \mathrm{kDa}$ IGFBP has recently been identified as a homolog of mammalian IGFBP-1. In the present study, an RIA for salmon IGFBP-1 was established and regulation of IGFBP-1 by food intake and temperature, and changes in IGFBP-1 during smoltification, were examined. Purified IGFBP-1 from serum was used for as a standard, for tracer preparation and for antiserum production. Cross-linking ${ }^{125}$ I-labelled IGFBP-1 with salmon IGF-I eliminated interference by IGFs. The RIA had little cross-reactivity with salmon 28 and $41 \mathrm{kDa}$ IGFBPs $(<0 \cdot 5 \%)$ and measured IGFBP-1 levels as low as $0 \cdot 1 \mathrm{ng} /$ $\mathrm{ml}$. Fasted fish had significantly higher IGFBP-1 levels than fed fish $(21 \cdot 6 \pm 4 \cdot 6 \mathrm{vs} 3 \cdot 0 \pm 2 \cdot 2 \mathrm{ng} / \mathrm{ml})$. Plasma IGFBP-1 was measured in individually tagged 1 -year-old coho salmon reared for 10 weeks under four different feeding regimes as follows: high constant ( $2 \%$ body weight/day), medium constant (1\% body weight/day), high variable ( $2 \%$ to $0.5 \%$ body weight/day) and medium variable ( $1 \%$ to $0.5 \%$ body weight/day). Fish fed with the high ration had lower IGFBP-1 levels than those fed with
\end{abstract}

the medium ration. Circulating IGFBP-1 increased following a drop in feeding ration to $0.5 \%$ and returned to the basal levels when feeding ration was increased. Another group of coho salmon were reared for 9 weeks under different water temperatures $\left(11\right.$ or $\left.7{ }^{\circ} \mathrm{C}\right)$ and feeding rations $(1 \cdot 75,1$ or $0.5 \%$ body weight/day). Circulating IGFBP-1 levels were separated by temperature during the first 4 weeks; a combined effect of temperature and feeding ration was seen in week 7 ; only feeding ration influenced IGFBP-1 level thereafter. These results indicate that IGFBP-1 is responsive to moderate nutritional and temperature changes. There was a clear trend that circulating IGFBP-1 levels were negatively correlated with body weight, condition factor (body weight/body length ${ }^{3} \times 100$ ), growth rates and circulating $41 \mathrm{kDa}$ IGFBP levels but not IGF-I levels. During parr-smolt transformation of coho salmon, IGFBP-1 levels showed a transient peak in late April, which was opposite to the changes in condition factor. Together, these findings suggest that salmon IGFBP-1 is inhibitory to IGF action. In addition, IGFBP-1 responds to moderate changes in dietary ration and temperature, and shows a significant negative relationship to condition factor.

Journal of Endocrinology (2006) 188, 101-110

\section{Introduction}

Insulin-like growth factor (IGF)-I is a potent mitogen that is essential to postnatal growth of animals. IGF-I exerts its actions through endocrine, paracrine and autocrine means by binding to IGF receptors. Regardless of the mode of action, the availability of IGF-I to bind receptors is regulated by a family of high-affinity IGF-binding proteins (IGFBPs). Six IGFBPs have been identified and characterized in mammals (Shimasaki \& Ling 1991, Rajaram et al. 1997). Depending on the type of IGFBP and the cellular environment, IGFBPs can either inhibit or potentiate the biological action of IGF-I. In addition, different tissues produce different IGFBPs. These features add to the complexity of IGF-I effects. Besides regulating IGF-I availability, IGFBPs have IGF-independent effects on cell growth (Ferry et al. 1999). 
IGF-I and IGFBPs are widely found among vertebrates including teleosts, and they appear to have co-evolved throughout the vertebrate lineage (Reinecke \& Collet 1998). Evidence for at least five IGFBP sequences (IGFBP-1 to -5) can be found in zebrafish (Danio rerio) and fugu (Fugu rubripes) genome databases and their sequences show 40-60\% homology to mammalian counterparts (Wood et al. 2005a). This conserved nature of IGFBP structure supports the concept that IGFBPs play a crucial role in regulating IGF-I action in vertebrates. In zebrafish, a series of studies based on IGFBP knockdown has shown that IGFBP-1, -2 and -3 regulate developmental rate under hypoxia, formation of the cardiovascular system and formation of the pharyngeal skeleton and inner ear (Kajimura et al. 2005, Li et al. 2005, Wood et al. 2005b). These studies argue for the importance of IGFBPs during development as well as during postnatal growth.

Endocrine IGF-I forms a large pool bound to IGFBPs in the blood. Although an essential role of endocrine IGF-I in the regulation of postnatal growth of mice has been questioned (Le Roith et al. 2001), its contribution to growth and metabolism is a subject of active investigation. Among the six IGFBPs present in the circulation of mammals, IGFBP-1 may be one of the most critical factors regulating the availability of circulating IGF-I to peripheral tissues (Lee et al. 1997). IGFBP-1 generally acts as an inhibitor of IGF-I action, presumably through sequestering free IGF-I. Unlike other IGFBPs, circulating IGFBP-1 shows a diurnal change in response to food intake (Busby et al. 1988, Cotterill et al. 1988). IGFBP-1 levels increase during fasting, and return to basal levels after a meal. This rapid change in IGFBP-1 is primarily due to the suppressive effect of insulin (Snyder \& Clemmons 1990). However, amino acids also influence the synthesis of IGFBP-1 in rats (Straus et al. 1993). The increase in IGFBP-1 may be a mechanism by which the action of IGF-I is blocked to redirect energy during malnutrition. Circulating IGFBP-1 is also increased under other catabolic states such as prolonged exercise, stress, hypoxia and critical illness (Lee et al. 1997). These responses of IGFBP-1 may be mediated, at least in part, by glucocorticoids such as cortisol. Glucocorticoid stimulates IGFBP-1 production, but its stimulatory effect is secondary to the suppressive effect of insulin in mammals (Unterman et al. 1991).

Candidates for fish IGFBP-1 have been detected in the circulation of several teleosts (Siharath et al. 1996, Park et al. 2000, Kelley et al. 2001, 2002, Kajimura et al. 2003). Western ligand blotting of fish plasma/serum typically reveals three IGFBP bands at 20-25, 25-30 and 40$50 \mathrm{kDa}$. The two smaller forms may be fish IGFBP-1 and/or -2 based on their size and response to fasting and stress (Kelley et al. 2001). This is further supported by hormone treatments with insulin and cortisol (Kelley et al. 2001, Kajimura et al. 2003). However, because the exact identity of the lower molecular weight IGFBPs is obscure; it is not known if their physiological response is due to a conserved nature of the same type of IGFBP, or a similar regulation of different types of IGFBPs. In addition, there is no specific assay for fish IGFBP-1 available at present, which makes a detailed quantitative analysis difficult. We have recently purified a $22 \mathrm{kDa}$ IGFBP from Chinook salmon serum, cloned its cDNA and identified it as a homolog of mammalian IGFBP-1 (Shimizu et al. 2005). Salmon IGFBP-1 lacks a PEST (Pro, Glu, Ser, Thr)-rich domain involved in rapid turnover of protein and an RGD (Arg-Gly-Asp) integrin recognition sequence (Shimizu et al. 2005), which might influence kinetics and function of circulating salmon IGFBP-1. Thus, the physiological role of IGFBP-1 in fish is unclear. The present study describes the development of an RIA for salmon IGFBP-1. With this RIA, we measured plasma IGFBP-1 in response to feeding ration and water temperature, and during the parr-smolt transformation; we then compared the IGFBP-1 levels to growth, condition factor, plasma IGF-I and $41 \mathrm{kDa}$ IGFBP.

\section{Materials and Methods}

Fish, sampling procedure and rearing experiments

Rearing conditions Yearling Chinook salmon (Oncorhynchus tshawytscha) and coho salmon (O. kisutch) were reared in fresh water at the Northwest Fisheries Science Center in Seattle (WA, USA). They were maintained in recirculated fresh water in circular fiberglass tanks under natural photoperiod; flowrate was $251 / \mathrm{min}$ and temperature ranged from $10 \cdot 5$ to $13 \cdot 0{ }^{\circ} \mathrm{C}$. Before the fish were used for experiments, they were fed standard rations $(0 \cdot 6-1 \cdot 0 \%$ body weight/day) of a commercial diet (Biodiet Grower; Bioproducts Inc., Warrenton, OR, USA). The experiments were conducted according to the guidelines of the University of Washington Institutional Animal Care and Use Committee.

Blood collection Fish were anesthetized in 0.05\% tricane methanesulfonate (MS-222; Argent Chemical Laboratories, Redmond, WA, USA). Blood was withdrawn by cutting the caudal peduncle and letting the blood flow into a heparinized glass tube. Plasma was collected after centrifugation at $700 \boldsymbol{g}$ for $15 \mathrm{~min}$ and stored at $-80{ }^{\circ} \mathrm{C}$ until use.

Effect of fasting Yearling Chinook salmon were fed at $52 \%$ of the maximum ration or fasted for 6 weeks (October to December). Blood was collected 6 weeks after treatment as described above.

Effect of feeding ration The detailed experimental design has been described in Beckman et al. (2004a). Briefly, yearling post-smolt coho salmon were individually tagged by passive integrated transponder (PIT) tags 
(Digital Angel, South St. Paul, MN, USA). From June to September, four groups of fish were fed at $2 \%$ (HiFeed) or $1 \%$ (MedFeed) body weight/day, and feeding rates were maintained (Constant) through the experiment or decreased to $0.5 \%$ body weight/day for 4 weeks and returned to their original feeding rates (Variable). These combinations created four feeding groups: HiFeedConstant, HiFeedVariable, MedFeedConstant and MedFeedVariable. Fish were sampled at 2 -week intervals. Instantaneous growth rate was calculated as: growth $(\% /$ day $)=\left(\ln s_{2}-\ln \right.$ $\left.s_{1}\right) \times\left(d_{2}-d_{1}\right)^{-1} \times 100$, where $s_{2}$ is length or weight on day $2, s_{1}$ is length or weight on day 1 and $d_{2}-d_{1}$ is the number of days between measurements. Condition factor was calculated as: body weight $(\mathrm{g}) /$ body length $(\mathrm{cm})^{3} \times$ 100. Five out of 147 fish were found to be precociously maturing males. IGFBP-1 levels in those fish were not included in the analysis since a disturbance in the relationship among IGF-I, $41 \mathrm{kDa}$ IGFBP and growth rate has been reported in maturing males (Beckman et al. 2004a).

Effects of temperature and feeding ration The detailed experimental design has been described in Beckman et al. (2004b). Briefly, individually tagged 1 -year-old coho salmon were reared at $11^{\circ} \mathrm{C}$ (Warm) or $7{ }^{\circ} \mathrm{C}$ (Cool), and fed at $1 \cdot 75 \%$ (HiFeed), $1 \cdot 0 \%$ (MedFeed) or $0.5 \%$ (LowFeed) for 9 weeks (June to August). These combinations created four treatment groups: WarmHiFeed, WarmMedFeed, CoolMedFeed and CoolLowFeed. Fish were sampled at 2- or 3-week intervals.

Parr-smolt transformation One-year-old coho salmon undergoing the parr-smolt transformation were sampled for blood every 2 weeks from March to July as described previously (Shimizu et al. 2003).

\section{Sample analyses}

Plasma IGF-I levels were measured by RIA as described in Shimizu et al. (2000). Briefly, IGF-I was first extracted from plasma by acid-ethanol and quantified by the RIA using recombinant salmon IGF-I as standard and tracer, and anti-recombinant barramundi IGF-I as primary antibody (GroPep Pty Ltd, Adelaide, Australia). Plasma $41 \mathrm{kDa}$ IGFBP was quantified by a homologous salmon RIA as described in Shimizu et al. (2003). In this RIA, tracer was prepared from cross-linking purified $41 \mathrm{kDa}$ IGFBP with ${ }^{125}$ I-labelled IGF-I.

\section{Purification of salmon IGFBP-1}

IGFBP-1 was purified from the serum of spawning male Chinook salmon (Shimizu et al. 2005). Briefly, salmon serum was first fractionated by ammonium sulfate precipitation and loaded onto an IGF affinity column. IGFBP-1 was eluted from the column with $0.5 \mathrm{M}$ acetic acid and further purified by reversed-phase HPLC on a Vydac C-4 column $(0.46 \times 5 \mathrm{~cm}$; Separation Group, Hesperia, CA, USA). Purified IGFBP-1 was quantified with the BCA protein assay kit (Pierce Chemical, Rockford, IL, USA), aliquoted into pre-lubricated microcentrifuge tubes (PGC Scientifcs, Frederick, MD, USA) and stored at $-80{ }^{\circ} \mathrm{C}$ until use.

\section{Preparation of antiserum}

Polyclonal antiserum against purified IGFBP-1 (antiIGFBP-1) was raised in a rabbit. Immunization of the rabbit was conducted in accordance with the guidelines of the Animal Care Committee of Hokkaido University, Japan. A total of $52 \mu \mathrm{g}$ purified protein in $1 \mathrm{ml}$ were emulsified in an equal volume of Freund's complete adjuvant (Iatoron, Tokyo, Japan). The rabbit was first immunized with $24 \mu \mathrm{g}$ antigen by lymph node injection and this was boosted subcutaneously with $28 \mu \mathrm{g}$ antigen 3 weeks after the first injection. Two weeks after the boost, blood was withdrawn from the ear vein and antiserum was collected after centrifugation. The antiserum was stored at $-30{ }^{\circ} \mathrm{C}$ until use.

\section{Preparation of tracers}

Purified IGFBP-1 was iodinated with $0.5 \mathrm{mCi} \mathrm{Na}^{125} \mathrm{I}$ (Amersham) by the chloramine-T method; $5 \mu \mathrm{g}$ IGFBP-1 in $31 \mu \mathrm{l}$ were mixed with $41 \mu \mathrm{l} 0.5 \mathrm{M}$ phosphate buffer, $\mathrm{pH} 7 \cdot 4$. The mixture was reacted with $20 \mu \mathrm{l}$ of $0 \cdot 4 \mathrm{mg} / \mathrm{ml}$ chloramine-T (Sigma) for $90 \mathrm{~s}$ and $20 \mu \mathrm{l}$ of $0.6 \mathrm{mg} / \mathrm{ml}$ metabisulfite was added to stop the reaction. Iodinated IGFBP-1 ( ${ }^{125}$ I-labelled IGFBP-1) was separated from free $\mathrm{Na}^{125}$ I using Biogel P-6 $(1 \times 18 \mathrm{~cm}$; BioRad $)$. An aliquot of ${ }^{125}$ I-labelled IGFBP-1 $(1.3 \mu \mathrm{g})$ was incubated with $4.3 \mu \mathrm{g}$ salmon IGF-I (GroPep Pty Ltd, Adelaide, Australia) for $2 \mathrm{~h}$ and they were cross-linked by disuccinimidyl suberate (Pierce Chemical) according to manufacturer's instruction. The ${ }^{125}$ I-labelled IGFBP-1 cross-linked with salmon IGF-I ( ${ }^{125}$ I-labeled IGFBP-1/IGF-I) was separated from non-reacted IGF-I by gel filtration using Sephadex G-50 $(1 \times 18 \mathrm{~cm}$, superfine; Pharmacia). Specific activity of the tracer estimated by the self-displacement assay was $69 \cdot 9 \mu \mathrm{Ci} / \mu \mathrm{g}$.

\section{RIA for salmon IGFBP-1}

The RIA was carried out in $12 \times 75 \mathrm{~mm}$ polystyrene test tubes. Purified IGFBP-1 was used for the standard. Standard $(100 \mu \mathrm{l})$ or plasma $(10-20 \mu \mathrm{l})$ diluted in $20 \mathrm{mM}$ phosphate, $150 \mathrm{mM} \mathrm{NaCl}, \mathrm{pH} 7 \cdot 4$ containing 1.0\% BSA and $0 \cdot 05 \%$ Triton-X-100 were incubated with $100 \mu \mathrm{l}$ anti-IGFBP-1 at a dilution of 1:2500 overnight at $4{ }^{\circ} \mathrm{C}$. Approximately 7000 c.p.m. of tracer in $100 \mu \mathrm{l}$ were added to the tubes and incubated overnight at $4{ }^{\circ} \mathrm{C}$. Free and antibody-bound tracers were separated by the addition of 


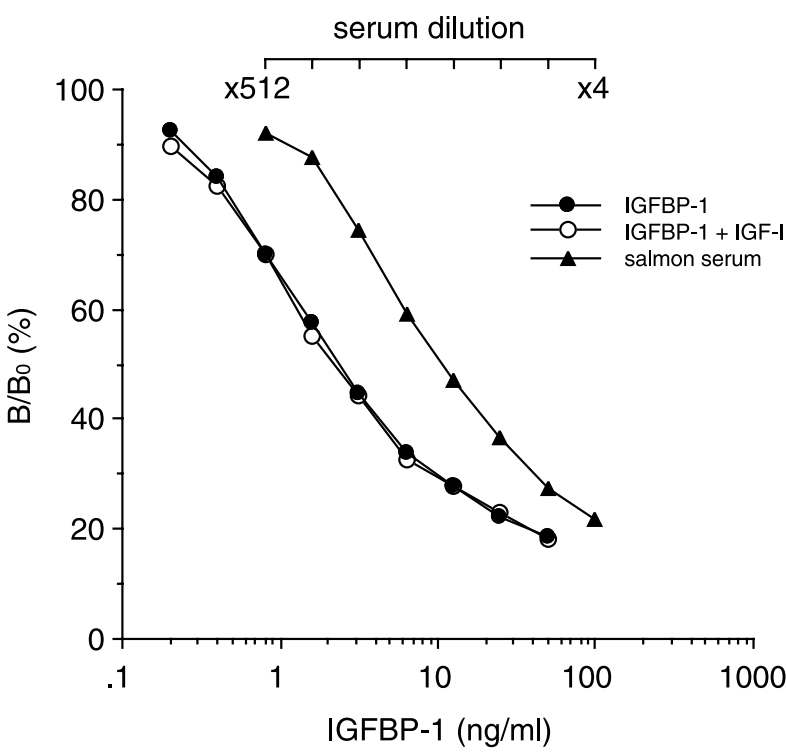

Figure 1 Displacement of ${ }^{125}$ I-labeled IGFBP-1/IGF-I by purified IGFBP-1 with or without IGF-I, and Chinook salmon serum. Increasing amounts of purified IGFBP-1, IGFBP-1 incubated with excess salmon IGF-I (1:100 molar ratio) and serum from spawning male Chinook salmon were added to the assay. Each point is the mean of duplicate samples.

0.5\% Pansorbin (Calbiochem-Novabiochem Corp., La Jolla, CA, USA). After incubating overnight at $4{ }^{\circ} \mathrm{C}$, tubes were centrifuged at $1350 \mathrm{~g}$ for $30 \mathrm{~min}$ and the supernatant was aspirated. Radioactivity in the pellets was measured by a gamma counter (Packard, Meriden, CT, USA). Standard and plasma samples were run in triplicate and duplicate respectively, unless otherwise indicated.

\section{Statistical analyses}

Values of IGFBP-1, IGF-I and body weight were natural$\log$ transformed to improve normality of distribution. Results of the experiments were analyzed by paired Student's $t$-test, unpaired $t$-test or one-way ANOVA followed by the Fisher's protected least-significant difference (PLSD) test using the Statview 512+ program (Abacus Concepts, Inc., Berkeley, CA, USA). Simple regression was used to assess the relationship of IGFBP-1 to growth and other parameters. Differences between groups were considered to be significant at $P<0 \cdot 05$.

\section{Results}

Specific binding of ${ }^{125}$ I-labeled IGFBP-1/IGF-I was displaced by increasing amounts of cold IGFBP-1 and the displacement with the serial dilution of salmon serum was parallel with the standard (Fig. 1). Adding an excess amount of salmon IGF-I $(1: 100$ molar ratio) to the

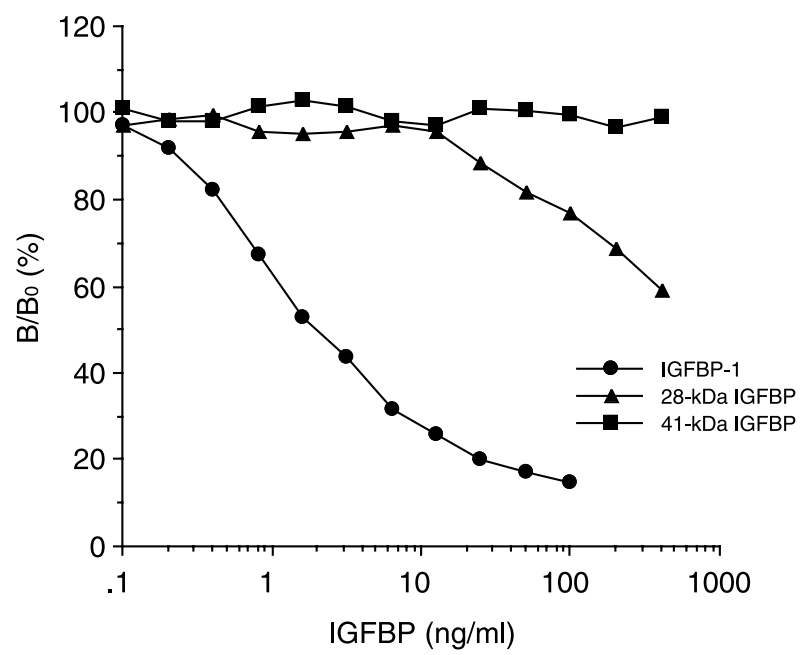

Figure 2 Cross-reactivity of salmon IGFBPs in the RIA. Displacement of tracer was assessed by adding increasing amounts of purified salmon IGFBP-1, and 28 and $41 \mathrm{kDa}$ IGFBPs to the assay. Each point is the mean of duplicate samples.

standard did not alter the curve. The same lack of effect was seen with human IGF-I and IGF-II at various ratios (1:1, 1:10 and 1:100; data not shown). Cross-reactivity of other salmon IGFBPs in the RIA using ${ }^{125}$ I-labeled IGFBP-1/IGF-I was examined (Fig. 2). The $41 \mathrm{kDa}$ IGFBP had no effect on displacing the binding. The $28 \mathrm{kDa}$ IGFBP showed some displacement at higher concentrations, but its cross-reactivity was less than $0.5 \%$, showing that the RIA is specific to IGFBP-1.

The specific and non-specific binding to the antiserum (1:2500 dilution) under the assay conditions were $24 \cdot 3 \pm 2 \cdot 0 \% \quad($ mean \pm S.E.M; $n=9)$ and $0 \cdot 70 \pm 0 \cdot 04 \%$ respectively. The half-maximal displacement $\left(\mathrm{ED}_{50}\right)$ occurred at $2 \cdot 28 \pm 0.13 \mathrm{ng} / \mathrm{ml} \quad(n=9)$. The $\mathrm{ED}_{80}$ and $\mathrm{ED}_{20}$ were $0.37 \pm 0.03$ and $25.98 \pm 1.54 \mathrm{ng} / \mathrm{ml}$ respectively. The minimal detection limit of the assay, defined as the mean count of the zero standard minus two standard deviations, was $0 \cdot 11 \pm 0.03 \mathrm{ng} / \mathrm{ml}$. The precision profile of the standard curve indicates that the functional sensitivity, defined as the concentration at which the interassay coefficient of variation is $<20 \%$, was $0.05 \mathrm{ng} / \mathrm{ml}$ $(n=9)$. The intra- and inter-assay coefficients of variation estimated using a control serum were $5 \cdot 3 \%(n=8)$ and $4 \cdot 6 \%(n=9)$ respectively.

The effect of IGFs on measured IGFBP-1 was assessed by adding varying concentrations of IGFs to the plasma (Table 1). Salmon IGF-I, human IGF-I and human IGF-II had no effect on IGFBP-1 levels up to $100 \mathrm{ng} / \mathrm{ml}$, whereas $1000 \mathrm{ng} / \mathrm{ml}$ human IGFs significantly altered measured IGFBP-1 levels (paired $t$-test, $P<0 \cdot 05$ ). However, because circulating IGF levels in salmon rarely exceed $100 \mathrm{ng} / \mathrm{ml}$ and because the rank of IGFBP-1 levels in individuals was not altered, the IGF effect is not, 
Table 1 Effect of IGFs on measured IGFBP-1 levels

\begin{tabular}{|c|c|c|}
\hline & Dose $(\mathrm{ng} / \mathrm{ml})$ & IGFBP-1 (ng/ml) \\
\hline $\begin{array}{l}\text { Treatment } \\
\text { Plasma only }\end{array}$ & & $23 \cdot 39 \pm 5 \cdot 46$ \\
\hline Plasma IGF-I & $\begin{array}{r}10 \\
100 \\
1000\end{array}$ & $\begin{array}{l}24 \cdot 42 \pm 6 \cdot 35 \\
24 \cdot 85 \pm 5 \cdot 51 \\
27 \cdot 18 \pm 7 \cdot 23\end{array}$ \\
\hline Human IGF-I & $\begin{array}{r}10 \\
100 \\
1000\end{array}$ & $\begin{array}{l}23 \cdot 31 \pm 2 \cdot 30 \\
24 \cdot 44 \pm 5 \cdot 95 \\
25 \cdot 98 \pm 6 \cdot 19^{*}\end{array}$ \\
\hline Human IGF-II & $\begin{array}{r}10 \\
100 \\
1000\end{array}$ & $\begin{array}{l}24 \cdot 03 \pm 5 \cdot 69 \\
25 \cdot 96 \pm 6 \cdot 74 \\
28 \cdot 56 \pm 7 \cdot 30^{*}\end{array}$ \\
\hline
\end{tabular}

Values are means \pm S.E. $(n=5)$.

*Values significantly different from control (paired $t$-test, $P<0 \cdot 05$ ).

in practice, a problem in the assay. Recoveries of purified IGFBP-1 added to plasma with and without salmon IGF-I were $90 \cdot 3-94 \cdot 9 \%$ and $94 \cdot 3-103 \cdot 3 \%$ respectively. These data show that IGFs do not interfere with the RIA. The RIA was also biologically validated as fasted fish had higher IGFBP-1 levels than fed fish $(21.6 \pm 4.6 \mathrm{ng} / \mathrm{ml}$ vs $3 \cdot 0 \pm 2 \cdot 2 \mathrm{ng} / \mathrm{ml}, n=11-14$ ), which is in agreement with Western blotting analysis (Shimizu et al. 2005).

Using the validated RIA, the response of the circulating IGFBP-1 to feeding ration was examined in post-smolt coho salmon (Fig. 3). When fish were reared under two different feeding rations (HiFeed and MedFeed), IGFBP-1 levels were higher in MedFeed groups (Fig. 3b). In the HiFeedVariable group, a decrease in feeding ration caused an increase in IGFBP-1 within 2 weeks. A subsequent increase in feeding back to the original amount caused a decrease in IGFBP-1 to the original level. In the MedFeedVariable group, the same trend was seen in response to a decrease in feeding ration except that the elevation in IGFBP-1 took 4 weeks to be significant.

The results of a simple regression of IGFBP-1 with growth and morphological parameters are shown in Table 2. For most dates, IGFBP-1 was negatively correlated with body weight, condition factor, growth rates and $41 \mathrm{kDa}$ IGFBP. No significant relation was found between IGFBP-1 and IGF-I on any given date (Table 2, Fig. 4b), whereas a consistent positive relation was evident between $41 \mathrm{kDa}$ IGFBP and IGF-I (Fig. 4a). IGFBP-1 appears to show the strongest negative relationship to condition factor (Table 2, Fig. 4c).

The effects of temperature and feeding ration were also examined in post-smolt coho salmon (Fig. 5). Although IGFBP-1 levels fluctuated during the first two sampling dates, they were separated by temperature (Fig. 5b). On the third sampling date, feeding ration became a major factor separating IGFBP-1 levels. Temperature may still have some effect as the differences in IGFBP-1 levels were close to being significant between WarmMedFeed and
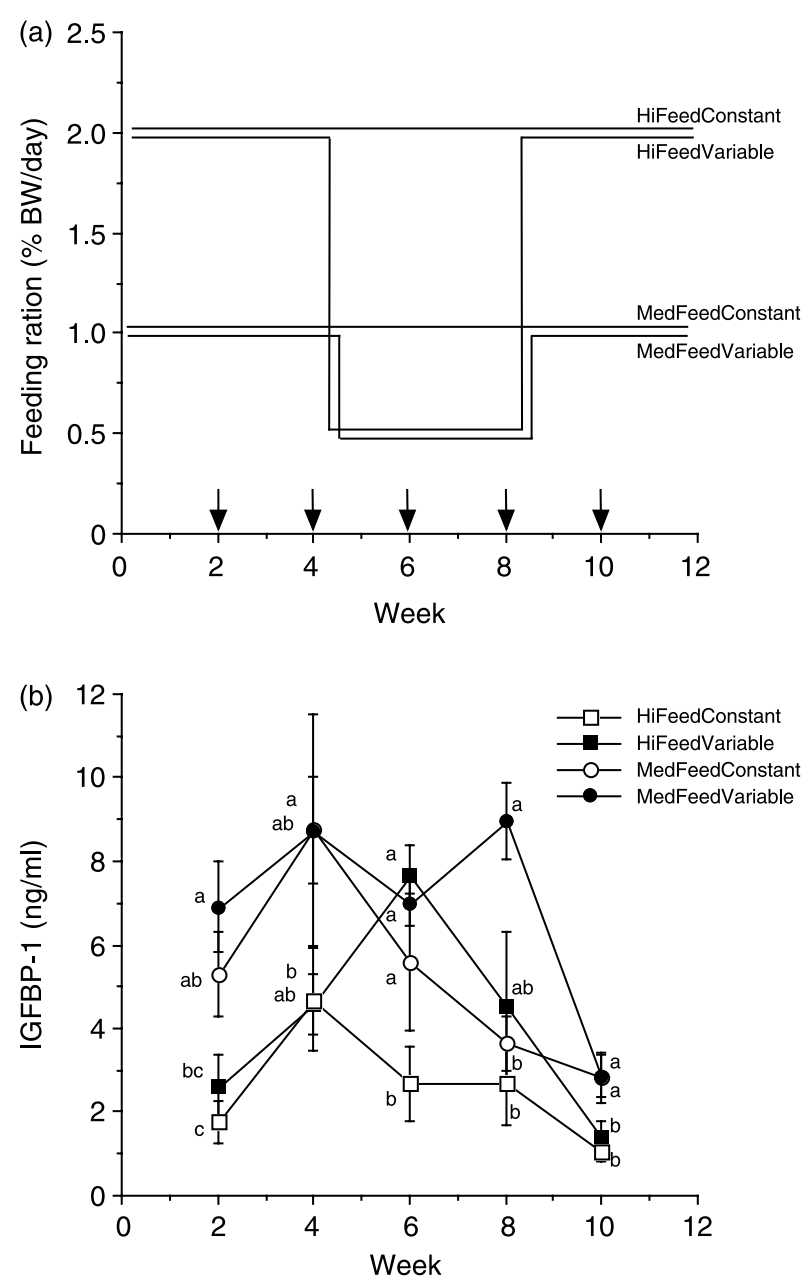

Figure 3 Effect of feeding ration and changes in feeding ration on plasma IGFBP-1 levels. (a) Experimental design. Post-smolt coho salmon were reared under high ( $2 \%$ body weight/day) or medium ( $1 \%$ body weight/day) rations (HiFeed or MedFeed respectively). Feeding rations were maintained (Constant) or changed (Variable) during the experiment. (b) Profiles of plasma IGFBP-1 levels measured by RIA. One-way ANOVA followed by Fisher's PLSD test was performed after natural-log-transforming IGFBP-1 values. Symbols sharing the same letters are not significantly different from each other for a given time point (Fisher's PLSD, $P<0 \cdot 05$ ); $n=6-10$ per point.

CoolMedFeed $(P=0 \cdot 0521)$. At the end of the experiment, IGFBP-1 levels were ranked by feeding ration only.

Changes in IGF-I, 41 kDa IGFBP, IGFBP-1 and condition factor were assessed during the parr-smolt transformation of coho salmon. IGFBP-1 showed a transient peak in late April, which corresponds to the second peak in IGF-I (Fig. 6a and c). The change in IGFBP-1 was opposite to the change in condition factor (Fig. $6 \mathrm{c}$ and d). The inverse relationship between IGFBP-1 and condition factor was best represented by an exponential curve fitting $\left(r^{2}=0 \cdot 416, P<0 \cdot 0001\right)$. 
Table 2 Negative relations of In IGFBP-1 to growth and metabolic parameters

\begin{tabular}{|c|c|c|c|}
\hline & Date & $P$ & $\mathbf{r}_{2}$ \\
\hline \multicolumn{4}{|c|}{$\begin{array}{l}\text { Week } \\
\text { vs length }\end{array}$} \\
\hline 2 & $26 \mathrm{Jul}$ & $0 \cdot 1294$ & $\mathrm{~ns}$ \\
\hline 4 & 10 Aug & $0 \cdot 1543$ & $\mathrm{~ns}$ \\
\hline 6 & 24 Aug & $0 \cdot 0216$ & $0 \cdot 23$ \\
\hline 8 & 8 Sep & $0 \cdot 2068$ & $\mathrm{~ns}$ \\
\hline 10 & 27 Sep & $0 \cdot 0416$ & $0 \cdot 11$ \\
\hline \multicolumn{4}{|c|}{ vs In length } \\
\hline 2 & $26 \mathrm{Jul}$ & $0 \cdot 0081$ & $0 \cdot 22$ \\
\hline 4 & 10 Aug & 0.0278 & $0 \cdot 16$ \\
\hline 6 & 24 Aug & $0 \cdot 0008$ & $0 \cdot 42$ \\
\hline 8 & 8 Sep & $0 \cdot 0185$ & $0 \cdot 29$ \\
\hline 10 & 27 Sep & 0.0069 & $0 \cdot 19$ \\
\hline \multicolumn{4}{|c|}{ vs condition factor } \\
\hline 2 & $26 \mathrm{Jul}$ & $<0 \cdot 0001$ & $0 \cdot 68$ \\
\hline 4 & 10 Aug & $0 \cdot 0004$ & $0 \cdot 35$ \\
\hline 6 & 24 Aug & $<0 \cdot 0001$ & 0.59 \\
\hline 8 & 8 Sep & $0 \cdot 0021$ & $0 \cdot 44$ \\
\hline 10 & 27 Sep & $<0 \cdot 0001$ & $0 \cdot 38$ \\
\hline \multicolumn{4}{|c|}{ vs IG length } \\
\hline 2 & $26 \mathrm{Jul}$ & 0.0523 & $\mathrm{~ns}$ \\
\hline 4 & 10 Aug & $0 \cdot 0596$ & ns \\
\hline 6 & 24 Aug & 0.0005 & $0 \cdot 44$ \\
\hline 8 & 8 Sep & $0 \cdot 0149$ & $0 \cdot 32$ \\
\hline 10 & 27 Sep & $0 \cdot 0006$ & $0 \cdot 28$ \\
\hline \multicolumn{4}{|c|}{ vs IG weight } \\
\hline 2 & 26 Jul & $0 \cdot 0002$ & $0 \cdot 38$ \\
\hline 4 & 10 Aug & $0 \cdot 1536$ & ns \\
\hline 6 & 24 Aug & $0 \cdot 0001$ & 0.52 \\
\hline 8 & 8 Sep & 0.0181 & $0 \cdot 29$ \\
\hline 10 & 27 Sep & $0 \cdot 0021$ & $0 \cdot 24$ \\
\hline \multicolumn{4}{|c|}{ vs In IGF-I } \\
\hline 2 & $26 \mathrm{Jul}$ & $0 \cdot 1390$ & ns \\
\hline 4 & 10 Aug & $0 \cdot 3001$ & ns \\
\hline 6 & 24 Aug & $0 \cdot 1632$ & ns \\
\hline 8 & 8 Sep & $0 \cdot 2105$ & $\mathrm{~ns}$ \\
\hline 10 & 27 Sep & $0 \cdot 0911$ & $\mathrm{~ns}$ \\
\hline \multicolumn{4}{|c|}{ vs $41 \mathrm{kDa} / \mathrm{GFBP}$} \\
\hline 2 & $26 \mathrm{Jul}$ & $0 \cdot 0071$ & $0 \cdot 22$ \\
\hline 4 & 10 Aug & 0.0033 & $0 \cdot 26$ \\
\hline 6 & 24 Aug & 0.0013 & $0 \cdot 40$ \\
\hline 8 & 8 Sep & $0 \cdot 1246$ & ns \\
\hline 10 & 27 Sep & 0.0007 & $0 \cdot 27$ \\
\hline
\end{tabular}

Data on instantaneous growth (IG), IGF-I and 41 kDa IGFBP levels are from Beckman et al. (2004a). Slopes of regression lines are all negative. In; natural log transformed; ns; not significant.

\section{Discussion}

We developed a specific RIA for salmon IGFBP-1, which is the first RIA for a non-mammalian IGFBP-1. This assay

Figure 4 Representative correlations between IGF-I and $41 \mathrm{kDa}$ IGFBP (a), IGF-I and IGFBP-1 (b), and condition factor and IGFBP-1 (c) on 26 July (week 2). Values of IGF-I and IGFBP-1 were natural-log transformed. Data on IGF-I and 41 kDa IGFBP are from Beckman et al. (2004a).
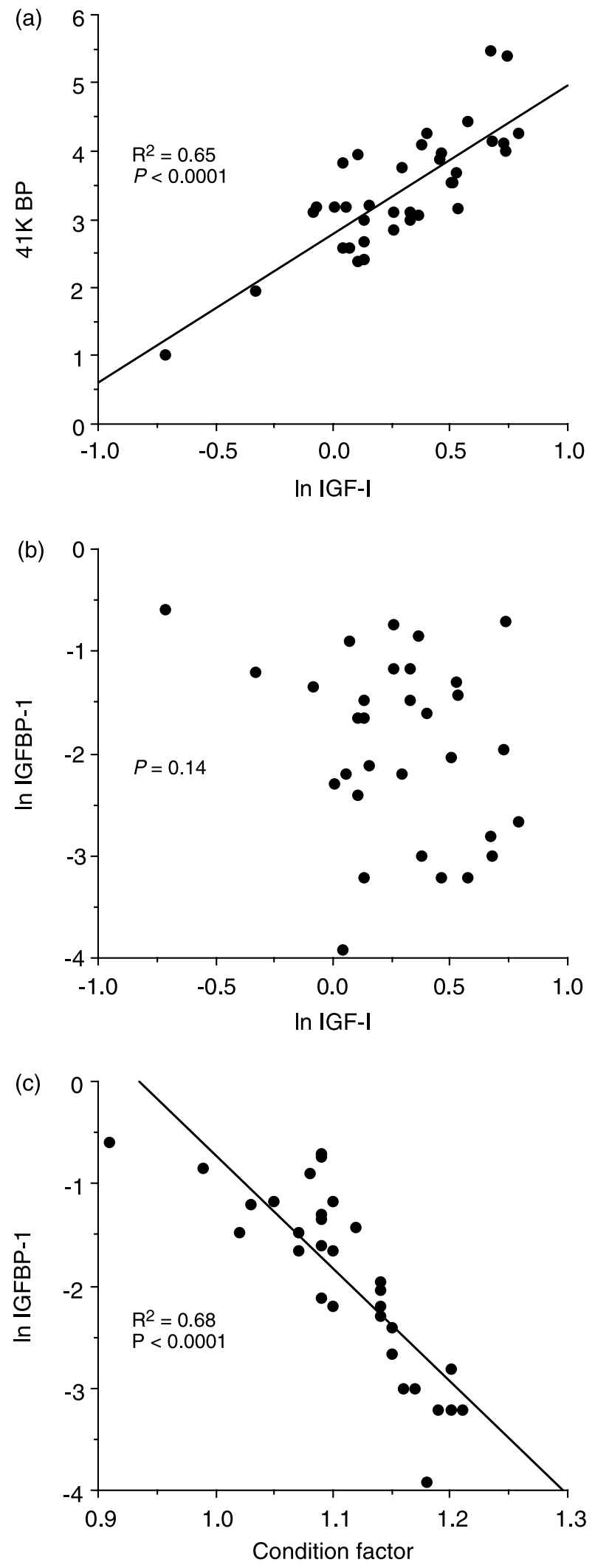

www.endocrinology-journals.org 

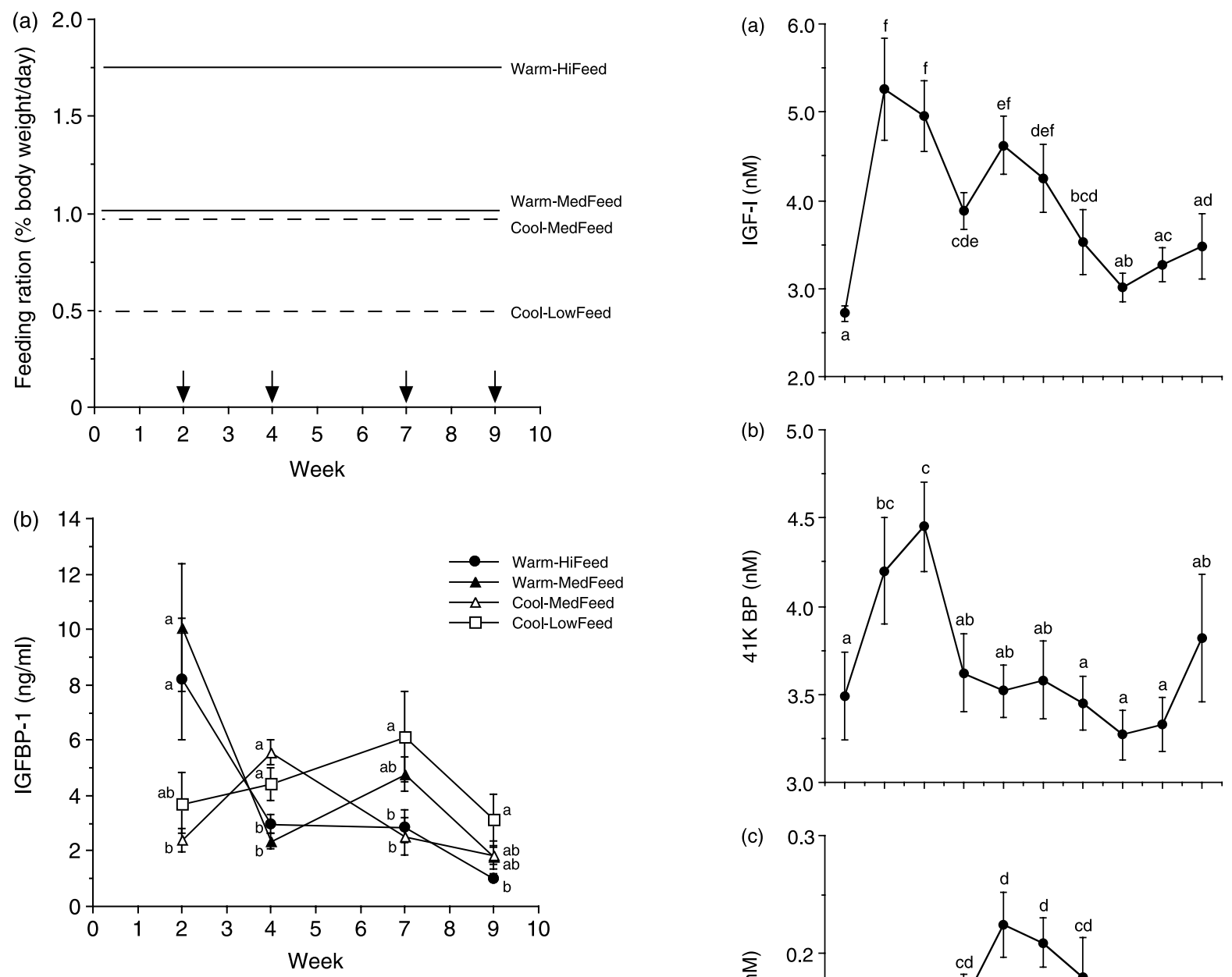

Figure 5 Effects of temperature and feeding ration on plasma IGFBP-1 levels. (a) Experimental design. Post-smolt coho salmon were reared in warm $\left(11^{\circ} \mathrm{C}\right)$ or cool $\left(7^{\circ} \mathrm{C}\right)$ water temperatures. Fish were fed at high $(1 \cdot 75 \%$ body weight/day), medium ( $1 \%$ body weight/day) or low ( $0.5 \%$ body weight/day) ration rates (HiFeed, MedFeed or LowFeed respectively). (b) Profiles of plasma IGFBP-1 levels measured by RIA. One-way ANOVA followed by Fisher's PLSD test were performed after natural-log-transforming IGFBP-1 values. Symbols sharing the same letters are not significantly different from each other for a given time point (Fisher's PLSD, $P<0 \cdot 05) ; n=6-11$ per point.
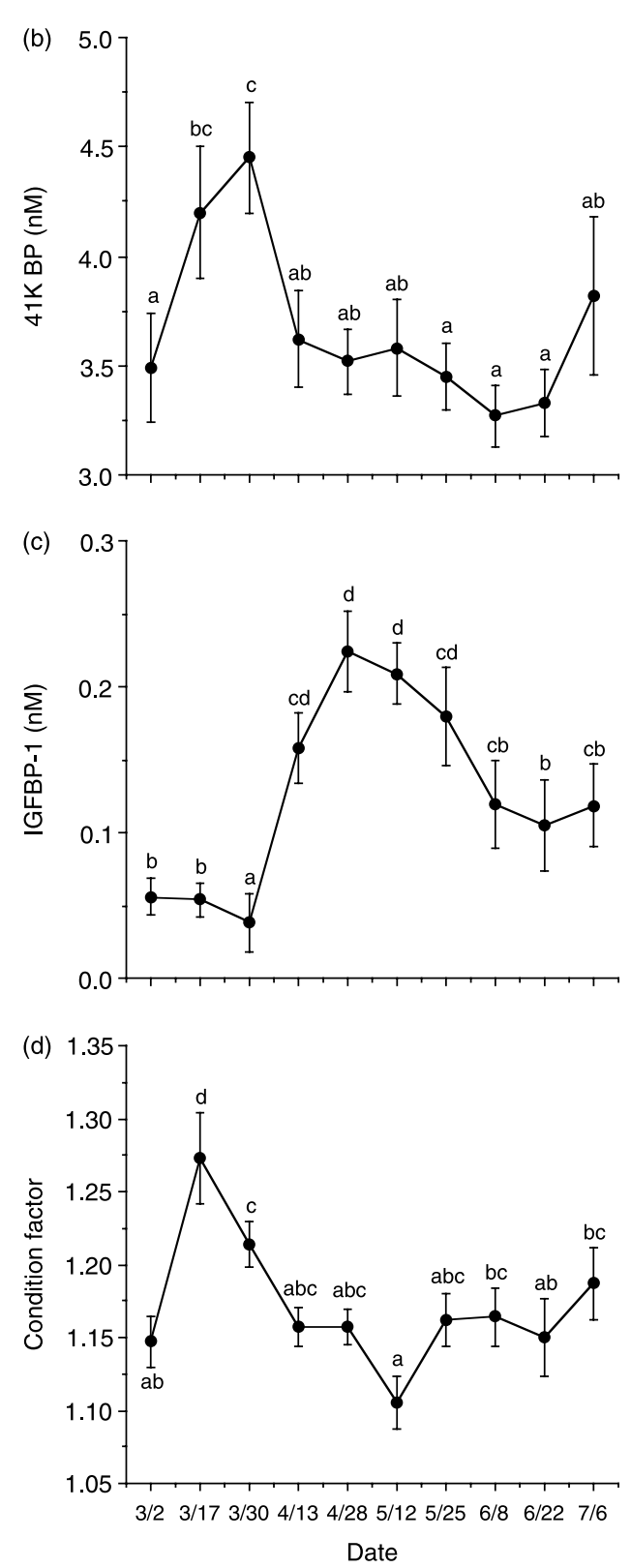

Figure 6 Changes in plasma IGF-I (a), 41 kDa IGFBP (b), IGFBP-1 (c) levels and condition factor (d) during parr-smolt transformation. Blood samples were collected from 1-year-old coho salmon during parr-smolt transformation. Condition factor was calculated as body weight $(\mathrm{g}) /$ body length $(\mathrm{cm})^{3} \times 100$; $n=11-12$ per point. Graphs for IGF-I and $41 \mathrm{kDa}$ IGFBP were reproduced from Shimizu et al. (2003) with permission. For statistical analyses, values of IGF-I, 41 kDa IGFBP and IGFBP-1 were natural-log transformed. Symbols sharing the same letters are not significantly different from each other for a given parameter (one-way ANOVA followed by Fisher's PLSD, $P<0 \cdot 05$ ). 
should facilitate quantitative studies of the role of IGFBP-1. Most previous studies of fish IGFBPs have used Western ligand blots for semi-quantifying IGFBP levels. RIAs have a number of advantages over the Western ligand blot analyses, including greater precision and the capacity to measure large numbers of samples. There are additional challenges in developing an RIA for a binding protein in that the ligand (IGF) in samples may interfere with assay performance. For example, we found during development of the RIA for salmon $41 \mathrm{kDa}$ IGFBP that IGF interfered with the assay when the binding protein was directly labeled with ${ }^{125} \mathrm{I}$ (Shimizu et al. 2003). Interference was avoided by using labeled IGF crosslinked to the $41 \mathrm{kDa}$ IGFBP. Similarly for the salmon IGFBP-1 RIA, IGF interference was avoided by using labeled IGFBP-1 cross-linked to IGF. Labeled IGF crosslinked to unlabeled IGFBP-1 resulted in a less sensitive assay, probably due to lower specific activity (data not shown). Eliminating interference by IGF allows direct assay of plasma samples without extraction. Although purified Chinook salmon IGFBP-1 was used for the standard and the label, the coho salmon samples showed parallel displacement, suggesting that the assay could be used for other salmonids.

Elevation of circulating IGFBP-1 during fasting is a well-known response in a wide range of vertebrates including fish (Busby et al. 1988, Siharath et al. 1996). In most experiments, the two extreme nutritional conditions of fasting and feeding ad libitum were compared. On the other hand, much less is known about the response of IGFBP-1 to moderate nutritional change. In humans, caloric restriction of $50 \%$ for 6 days resulted in an increase in plasma IGFBP-1 in adults but not in children (Smith et al. 1995). Dietary energy restriction of 42.5 and $56 \%$ for 2 weeks had no effect on IGFBP-1 in dogs (Maxwell et al. 1998). Plasma IGFBP-1 levels decreased in guinea pigs fed rations of $70 \%$ of ad libitum feeding levels for 80 days (Sohlström et al. 1998). These results indicate that changes in IGFBP-1 in response to moderate feed restriction differ depending on stage and species. In the present study, the effect of ration on circulating IGFBP-1 was assessed in growing coho salmon. When the ration was reduced from $2 \%$ to $0.5 \%$ body weight per day, IGFBP- 1 increased at 2 weeks, whereas reducing the ration from $1 \%$ to $0.5 \%$ increased IGFBP-1 at 4 weeks. The later response with the more moderate reduction in ration suggests that the relative change in food intake is an important cue for inducing IGFBP-1. Alternatively, the fish fed on the higher ration (2\%) may be more sensitive to a reduction in food intake. The response of IGF-I and $41 \mathrm{kDa}$ IGFBP levels to ration reduction was generally opposite to that of IGFBP-1; they declined by 2 weeks after the $2 \%$ to $0.5 \%$ ration change (Beckman et al. 2004a). However, IGF-I did not decline in response to the $1 \%$ to $0.5 \%$ ration change, suggesting that IGFBP-1 may be more sensitive than IGF-I to ration change. Overall, the results indicate that IGFBP-1 is quite responsive to moderate ration change in salmon.

Environmental temperature is a crucial factor affecting metabolic rate of poikilotherms and the change in the metabolic setting with temperature, in turn, may alter the endocrine system. In Atlantic salmon (Salmo salar), hormonal changes associated with parr-smolt transformation were limited by lowering temperature (McCormick et al. 2000). A relatively short-term effect of temperature change (1 week) on insulin and IGF-I levels has been reported in coho salmon; a drop of temperature increased insulin and decreased IGF-I respectively (Larsen et al. 2001). Temperature also affects IGFBP in catfish (Ictalurus punctatus) (Johnson et al. 2003). Increasing temperature from 21 to $26{ }^{\circ} \mathrm{C}$ resulted in an induction of a $19 \mathrm{kDa}$ IGFBP whereas other IGFBPs remained unchanged. We have previously shown that salmon $41 \mathrm{kDa}$ IGFBP as well as IGF-I was temporally affected by temperature (Beckman et al. 2004b). In the present study, temperature change appeared to disrupt IGFBP-1 levels for at least 6 weeks as feeding level had little relation to plasma IGFBP-1 level until the seventh week of the experiment. After this acclimation period feeding level again appeared to be the primary determinant of IGFBP-1 as fish receiving less feed had higher levels and temperature had no effect on IGFBP-1 at the end of the experiment ( 9 weeks). These results suggest that it took 9 weeks for fish to adjust IGFBP-1 levels to the different temperature. The response of IGF-I, $41 \mathrm{kDa}$ IGFBP and IGFBP-1 to temperature change appears to differ. Lowering temperature resulted in a decrease in IGF-I and an increase in $41 \mathrm{kDa}$ IGFBP (Beckman et al. 2004b), whereas the IGFBP-1 response occurred in both directions. Gabillard et al. (2003) found that higher environmental temperature increased plasma $\mathrm{GH}$ levels in rainbow trout (O. mykiss). These findings suggest that temperature influences the somatotropic axis not simply through changing metabolic rate, which would result in all components of the axis changing similarly, but through specific responses for each component.

We also studied changes in circulating IGFBP-1 levels during smoltification, which is a pre-adaptation to ocean life accompanied by many hormonal changes including IGF-I (Dickhoff et al. 1997). Shimizu et al. (2003) reported that IGF-I levels showed two peaks during the smolting process; one in late March and one in late April. In the present study, plasma IGFBP-1 levels in the same samples used in Shimizu et al. (2003) showed a peak in late April, which corresponds to the second peak in IGF-I. However, IGFBP-1 and IGF-I levels were not correlated (data not shown) similar to the result in the feeding experiment. The increase in IGFBP-1 may be driven by an increase in cortisol, which becomes elevated during smoltification. In contrast, a peak of $41 \mathrm{kDa}$ IGFBP corresponded to the first peak in IGF-I, and their levels were positively correlated. These findings indicate that the IGF-I/IGFBP system changes during smoltification and 
suggest different roles for IGFBP-1 and $41 \mathrm{kDa}$ IGFBP in this process. The significance of the change in IGF binding proteins during smoltification is unknown.

We analyzed the relationship of IGFBP-1 to growth, fish size, condition factor, IGF-I and $41 \mathrm{kDa}$ IGFBP in individually tagged fish from the feeding experiment. Simple regression analysis revealed a clear trend that circulating IGFBP-1 level is negatively correlated with body weight, condition factor, growth rate and $41 \mathrm{kDa}$ IGFBP. These results support the hypothesis that IGFBP-1 is generally inhibitory to growth. Our findings are in agreement with studies in humans showing that IGFBP-1 is inversely related to anthropometric and endocrine factors (Travers et al. 1998, Voskuil et al. 2001, Wolk et al. 2004). Among the growth and morphometric factors tested in the present study, the strongest and most consistent negative relation was with condition factor (body weight/body length ${ }^{3}$ ). The negative relation between IGFBP-1 and condition factor was present in both sets of data analyzed; one from the ration manipulation and the other from the smoltification study. In the experiment where some fish received reduced ration, the decline in condition factor was due to a greater loss in weight relative to growth in length. Growth in length ceased but did not become negative, and some individual fish lost weight due to dietary restriction. The group that went from $2 \%$ to $0.5 \%$ ration had a significant weight loss by 2 weeks. In the study of smoltification, it is well established that the decline in condition factor is due to a more rapid growth in length relative to growth in weight (Winans \& Nishioka 1987). Thus, the inverse relationship between IGFBP-1 and condition factor is present during nutritional restriction and development of growing fish. In humans a strong relationship was observed between IGFBP-1 and body mass index (BMI; body weight/ height ${ }^{2}$ ), which is similar to the condition factor in fish. The inverse relationship in humans held for early pubertal children (Travers et al. 1998), pre-menopausal women (Voskuil et al. 2001), and middle-aged and elderly men (Wolk et al. 2004). The underlying mechanisms for the relationship of lean body index and high IGFBP-1 in humans and salmon is not known, but invites additional study in other species.

Findings from the present study support different roles of salmon $41 \mathrm{kDa}$ IGFBP and IGFBP-1 in regulating IGF-I activity. The $41 \mathrm{kDa}$ IGFBP is the main carrier of circulating IGF-I as its levels are generally highly correlated with IGF-I levels (Shimizu et al. 2003, Beckman et al. 2004a,b). On the other hand, salmon IGFBP-1 can not be a main carrier of IGF-I because of: (a) the lack of correlation with IGF-I levels and (b) the fact that the molar concentrations of IGFBP-1 in blood are an order of magnitude lower than those of total IGF-I and $41 \mathrm{kDa}$ IGFBP. In mammals, IGFBP-1 is postulated to be an important regulator of free IGF-I levels, which are biologically active and available to bind with IGF receptor
(Frystyk et al. 1994). This hypothesis has recently been tested by in vivo infusion of human IGFBP-1 into catheterized rats. Infused human IGFBP-1 did not significantly alter the plasma concentration of total IGF-I, but decreased circulating free IGF-I levels (Lang et al. 2003). Although free IGF-I levels were not measured in the present study, a possible role of salmon IGFBP-1 in the regulation of free IGF-I may explain why IGFBP-1 shows no correlation with total IGF-I despite negative correlation with growth rates.

In conclusion, we developed a specific RIA for salmon IGFBP-1 for the first time and analyzed its regulation by food intake and temperature, and during smoltification. A range of moderate nutritional and temperature manipulations indicate that they are critical factors controlling circulating salmon IGFBP-1 levels. Regression analysis revealed that plasma IGFBP-1 is negatively correlated with growth and condition factor, among other factors. These findings suggest that the growth-inhibitory action of IGFBP-1 is conserved in salmon.

\section{Acknowledgements}

We thank Brad A. Gadberry of NOAA Fisheries, and Paul J. Parkins and Kathleen A. Cooper, School of Aquatic and Fishery Sciences, University of Washington, Seattle, WA, USA for maintenance of the fish and for their technical support.

\section{Funding}

This project was supported by a National Research Initiative Competitive Grant (2003-35206-13631) from the USDA Cooperative State Research, Education, and Extension Service, and by Bonneville Power Administration (Projects 2002-003100 and 1993-05600). The authors declare that there is no conflict of interest that would prejudice the impartiality of this scientific work.

\section{References}

Beckman BR, Shimizu M, Gadberry BA \& Cooper KA 2004a Response of the somatotropic axis of juvenile coho salmon to alterations in plane of nutrition with an analysis of the relationships among growth rate and circulating IGF-I and $41 \mathrm{kDa}$ IGFBP. General and Comparative Endocrinology 135 334-344.

Beckman BR, Shimizu M, Gadberry BA, Parkins PJ \& Cooper KA $2004 b$ The effect of temperature change on the relations among plasma IGF-I, 41-kDa IGFBP, and growth rate in postsmolt coho salmon. Aquaculture 241 601-619.

Busby WH, Snyder DK \& Clemmons DR 1988 Radioimmunoassay of a 26,000-dalton plasma insulin-like growth factor-binding protein: control by nutritional variables. Journal of Clinical Endocrinology and Metabolism 67 1225-1230.

Cotterill AM, Cowell CT, Baxter RC, McNeil D \& Silinik M 1988 Regulation of the growth hormone-independent growth 
factor-binding protein in children. Journal of Clinical Endocrinology and Metabolism 67 882-887.

Dickhoff WW, Beckman BR, Larsen DA, Duan C \& Moriyama S 1997 The role of growth in endocrine regulation of salmon smoltification. Fish Physiology and Biochemistry 17 231-236.

Ferry RJ Jr, Cerri RW \& Cohen P 1999 Insulin-like growth factor binding proteins: new proteins, new functions. Hormone Research 51 53-67.

Frystyk J, Skjaerbaek C, Dinesen B \& Orskov H 1994 Free insulin-like growth factors (IGF-I and IGF-II) in human serum. FEBS Letters 348 185-191.

Gabillard JC, Weil C, Rescan PY, Navarro I, Gutierrez J \& Le Bail PY 2003 Environmental temperature increases plasma GH levels independently of nutritional status in rainbow trout (Oncorhynchus mykiss). General and Comparative Endocrinology 133 17-26.

Johnson J, Silverstein J, Wolters WR, Shimizu M, Dickhoff WW \& Shepherd BS 2003 Disparate regulation of insulin-like growth factor binding proteins in a primitive, ictalurid, teleost (Ictalurus punctatus). General and Comparative Endocrinology 134 122-130.

Kajimura S, Hirano T, Visitacion N, Moriyama S, Aida K \& Grau EG 2003 Dual mode of cortisol action on GH/IGF-I/IGF binding proteins in the tilapia, Oreochromis mossambicus. Journal of Endocrinology 178 91-99.

Kajimura S, Aida K \& Duan C 2005 Insulin-like growth factor-binding protein-1 (IGFBP-1) mediates hypoxia-induced embryonic growth and developmental retardation. PNAS 102 1240-1245.

Kelley KM, Haigwood JT, Perez M \& Galima MM 2001 Serum insulin-like growth factor binding proteins (IGFBPs) as markers for anabolic/catabolic condition in fishes. Comparative Biochemistry and Physiology 129-B 229-236.

Kelley KM, Schmidt KE, Berg L, Sak K, Galima MM, Gillespie C, Balogh L, Hawayek A, Reyes JA \& Jamison M 2002 Comparative endocrinology of the insulin-like growth factor-binding protein. Journal of Endocrinology 175 3-18.

Lang CH, Vary TC \& Frost RA 2003 Acute in vivo elevation of insulinlike growth factor (IGF) binding protein-1 decreases plasma free IGF-I and muscle protein synthesis. Endocrinology 144 3922-3933.

Larsen DA, Beckman BR \& Dickhoff WW 2001 The effect of low temperature and fasting during the winter on metabolic stores and endocrine physiology (insulin, insulin-like growth factor-I, and thyroxine) of coho salmon, Oncorhynchus kisutch. General and Comparative Endocrinology 123 308-323.

Le Roith D, Bondy C, Yakar S, Liu JL \& Butler A 2001 The somatomedin hypothesis: 2001. Endocrine Reviews 22 53-74.

Lee PD, Giudice LC, Conover CA \& Powell DR 1997 Insulin-like growth factor binding protein-1: recent findings and new directions. Proceedings of the Society for Experimental Biology and Medicine 216 319-357.

Li Y, Xiang J \& Duan C 2005 Insulin-like growth factor-binding protein-3 plays an important role in regulating pharyngeal skeleton and inner ear formation and differentiation. Journal of Biological Chemistry $2803613-3620$.

McCormick SD, Moriyama S \& Björnsson BT 2000 Low temperature limits photoperiod control of smolting in Atlantic salmon through endocrine mechanisms. American Journal of Physiology: Regulatory, Integrative and Comparative Physiology 278 R1352-R1361.

Maxwell A, Butterwick R, Yateman M, Batt RM, Cotterill A \& Camacho-Hubner C 1998 Nutritional modulation of canine insulin-like growth factors and their binding proteins. Journal of Endocrinology 158 77-85.

Park R, Shepherd BS, Nishioka RS, Grau EG \& Bern HA 2000 Effects of homologous pituitary hormone treatment on serum insulin-like growth-factor-binding proteins (IGFBPs) in hypophysectomized tilapia, Oreochromis mossambicus, with special reference to a novel 20-kDa IGFBP. General and Comparative Endocrinology 117 404-412.

Rajaram S, Baylink DJ \& Mohan S 1997 Insulin-like growth factor-binding proteins in serum and other biological fluids: regulation and functions. Endocrine Reviews 18 801-831.
Reinecke M \& Collet C 1998 The phylogeny of the insulin-like growth factors. International Review of Cytology 183 1-94.

Shimasaki S \& Ling N 1991 Identification and molecular characterization of insulin-like growth factor binding proteins (IGFBP-1, -2, -3, -4, -5 and -6). Progress in Growth Factor Research 3 243-266.

Shimizu M, Swanson P, Fukada H, Hara A \& Dickhoff WW 2000 Comparison of extraction methods and assay validation for salmon insulin-like growth factor-I using commercially available components. General and Comparative Endocrinology 119 26-36.

Shimizu M, Hara A \& Dickhoff WW 2003 Development of an RIA for salmon $41 \mathrm{kDa}$ IGF-binding protein. Journal of Endocrinology 178 275-283.

Shimizu M, Dickey JT, Fukada H \& Dickhoff WW 2005 Salmon serum $22 \mathrm{kDa}$ insulin-like growth factor-binding protein (IGFBP) is IGFBP-1. Journal of Endocrinology 184 26-276.

Siharath K, Kelley KM \& Bern HA 1996 A low-molecular-weight (25-kDa) IGF-binding protein is increased with growth inhibition in the fasting striped bass, Morone saxatilis. General and Comparative Endocrinology 102 307-316.

Smith WJ, Underwood LE \& Clemmons DR 1995 Effects of caloric or protein restriction on insulin-like growth factor-I (IGF-I) and IGF-binding proteins in children and adults. Journal of Clinical Endocrinology and Metabolism 80 443-449.

Snyder DK \& Clemmons DR 1990 Insulin-dependent regulation of insulin-like growth factor-binding protein-1. Journal of Clinical Endocrinology and Metabolism 71 1632-1636.

Sohlström A, Katsman A, Kind KL, Grant PA, Owens PC, Robinson JS \& Owens JA 1998 Effects of acute and chronic food restriction on the insulin-like growth factor axis in the guinea pig. Journal of Endocrinology 157 107-114.

Straus DS, Burke EJ \& Marten NW 1993 Induction of insulin-like growth factor binding protein-1 gene expression in liver of protein-restricted rats and in rat hepatoma cells limited for a single amino acid. Endocrinology 132 1090-1100.

Travers SH, Labarta JI, Gargosky SE, Rosenfeld RG, Jeffers BW \& Eckel RH 1998 Insulin-like growth factor binding protein-I levels are strongly associated with insulin sensitivity and obesity in early pubertal children. Journal of Clinical Endocrinology and Metabolism $\mathbf{8 3}$ 1935-1939.

Unterman TG, Oehler DT, Murphy LJ \& Lacson RG 1991 Multihormonal regulation of insulin-like growth factor-binding protein-1 in rat H4 IIE hepatoma cells: the dominant role of insulin. Endocrinology 128 2693-2701.

Voskuil DW, Bueno de Mesquita HB, Kaaks R, van Noord PA, Rinaldi S, Riboli E, Grobbee DE \& Peeters PH 2001 Determinants of circulating insulin-like growth factor (IGF)-I and IGF binding proteins $1-3$ in premenopausal women: physical activity and anthropometry (Netherlands). Cancer Causes and Control 12 951-958.

Winans GA \& Nishioka RS 1987 A multivariate description of changes in body shape of coho salmon (Oncorhynchus kisutch) during smoltification. Aquaculture 66 235-245.

Wolk K, Larsson SC, Vessby B, Wolk A \& Brismar K 2004 Metabolic, anthropometric, and nutritional factors as predictors of circulating insulin-like growth factor binding protein-1 levels in middle-aged and elderly men. Journal of Clinical Endocrinology and Metabolism 89 1879-1884.

Wood AW, Duan C \& Bern HA 2005a Insulin-like growth factor signaling in fish. International Review of Cytology 243 215-285.

Wood AW, Schlueter PJ \& Duan C $2005 b$ Targeted knockdown of insulin-like growth factor binding protein-2 (IGFBP-2) disrupts cardiovascular development in zebrafish embryos. Molecular Endocrinology 19 1024-1034.

Received 18 October 2005

Accepted 24 October 2005

Made available online as an Accepted Preprint

15 November 2005 